Philosophy and Progress: Vols. LV-LVI, January-June, July-December, 2014 ISSN 1607-2278 (Print), DOI : http://dx.doi.org/10.3329/pp.v55i1-2.26395

\section{SOCIAL REFORM IN COLONIAL BENGAL: REVISITING VIDYASAGAR}

\author{
Manmay Zafar*
}

\begin{abstract}
This paper looks at Vidyasagar's programme for widow marriage while also discussing his campaign against Kulin Brahmin polygamy, child marriage and prostitution - some of the evils that plagued nineteenth-century Bengali society. Vidyasagar's diligent effort for the legalisation of widow marriage ultimately paid off in 1856 as the British colonial administrators drafted widow marriage into law. The two tracts that Vidyasagar published in 1856 in favour of widow marriage have been looked into some detail as well as opposition to his programme from none other than Bankimchandra Chattopadhyay, arguably the greatest Bengali novelist till date. Statistically speaking, not many widows married under the Hindu Widow's Remarriage Act, making the Act, according to some critics, almost a dead letter. However, whether statistics alone does justice to the long-term impact Vidyasagar's movement has had on Bengal's social and intellectual life is also discussed.
\end{abstract}

\footnotetext{
Associate Professor, Department of English, Jahangirnagar University, Savar, Dhaka 1342. Email: manmay.zafar@gmail.com
}

In nineteenth-century colonial Bengal, various patriarchal ideologies governing the lives of women were gradually challenged, despite stern social disapprobation, by the likes of Raja Rammohan Roy (1772-1833), Ishvar Chandra Vidyasagar (1820-1891) and the radical Young Bengal. Thanks to these pioneers, the nineteenth-century is now generally regarded as the time when a number of reform movements geared toward the emancipation of women were undertaken. There was, however, a marked difference between the approach adopted by the Young Bengal and that followed by Rammohan and Vidyasagar. While the former wanted to startle and refashion Bengali Hindu society through their maverick words and deeds, which included feasting on beef or naming and shaming Kulin Brahmins for polygamy, Rammohan and Vidyasagar opted for changing the society from within through activist politics, strengthened by their tracts on prohibition of widow immolation and sanctioning of widow marriage. Instead of being radical and (largely) dismissive of contemporary society like the Young Bengal, Rammohan and Vidyasagar tried to engage their compatriots with a view to changing long-held beliefs about the condition of women in Bengal. Instead of shocking society at its core, they decided to appeal sometimes to the head and sometimes to the heart of Bengalis, as and when their tactical moves allowed. True, they were dubbed 'half-liberals' by the Young Bengal who became impatient with their 'go slow' policy, but their often painstaking efforts gradually paid off as the year 1829 saw widow immolation being banned by the British colonial administration in India, while the year 1856 borewitness to the passing of the Hindu Widow's Remarriage Act XV. Following these legislative changes, intercourse with wives below the age of twelve was also criminalised in 1891, although child marriage was not (Ray, 1991: 6). It is in this context that I focus on Vidyasagar 
to revisit his programme for widow marriage, commonly known as Bidhaba Bibahain Bengal.

During his lifetime, Vidyasagar campaigned against Kulin Brahmin polygamy, child marriage and prostitution. He also argued strongly in favour of women's education, thus contributing to the emergence of what came to be known as the Bengali bhadramahila (i.e. gentlewoman). However, it was his concern for Bengal's widows that largely defined his life, work and achievement for succeeding generations. His almost crusade-like effort to have widow marriage legalised proved to be the most divisive act of his career, generating a large body of writings and petitions from various religious and ideological quarters, both for and against widow marriage (Ghose, 1973: 239-78). In response, in a couple of tracts, Vidyasagar diligently engaged with criticism levelled against his project (Vidyasagar, 2012: 57-206). Importantly, he presented detailed re-readings of the Shastra or Hindu religious scriptures not merely to refute conventional wisdom against widow marriage but also to find support for it.

Polygamy, child marriage, ascetic widowhood and prostitution as well as denial of education to women are now widely believed to be the major issues affecting the lives of women in nineteenth-century Bengal (see Anisuzzaman 2000, Chakrabarti, 1998 \& Murshid, 1984). Child marriage often leading to untimely widowhood almost became the norm. Prominent Bengali intellectuals of the time such as Bankimchandra Chattopadhyay (1838-1894) and Vidyasagar himself were married to minors by their parents. Bankimchandra was married to a 5-year old when he was 11 . Vidyasagar was 14 when he was married to an 8-year old girl (Chowdhury 1997: 280). The Kulin Brahmin polygamy also led to many social ills. The Kulins, who happened to be the highest sect of Brahmins, were especially notorious for being polygamous. Collecting handsome dowries through multiple marriages almost became their profession. Many Kulin wives could meet their husbands only once or twice during their lifetime and it was not uncommon for all of them to be burnt at the stake for the sake of the one husband they had shared amongst themselves (Chakrabarti, 1998: 8-9). The polygamous nature of the Kulins were well exposed in 1836 by the Young Bengal in their journal Gananneshan ("Search for Knowledge") in which they published a list of Kulin Brahmins, some of whom had married more than 60 times (Chakrabarti, 1998: 92)

Brothels, where many Kulin wives deserted by their husbands ended up, gradually became an important part of Bengali life, and often used as a meeting place by Bengali baboos. Nirad C. Chaudhuri, in his influential Bangali Jibane Ramani("Women in Bengali Life") (1968), observed how the status of housewives was much lower than those involved in prostitution. Outside the zenana, Bengali housewives hardly had any existence, while considerable power was yielded by the likes of Baknapiyari, Damragopi, Omda Khanum and Munnijan, i.e. famous prostitutes of Kolkata zealously courted by powerful Bengali men (Chaudhuri, 1968:72). Saratchandra Chattopadhyay's (1876-1938) Devdas (1917, rpt. 2002), a popular Bengali novella, which has retained cult status even till today both in Bangladesh and India, went as far as romanticising the profession of prostitution while lending Bengali gentry's visitations of brothels the kind of normalcy and social acceptance it used to enjoy. Contemporary Bengali satirical writings were rife with descriptions of salacious rendezvous between Bengali baboos and their mistresses (see Murshid, 1984). In Kolikata Kamalalaya ("Kolkata, the House of Fortune") (1823), a famous satire by Bhabanicharan Bandyopadhyay (1787-1848), the life of baboos was presented 
as peppered with much wit and humour. However, it goes without saying that no such luxury was afforded to the wives of the baboos concerned.

As for the widows, by the time of Vidyasagar, they were saved from their husband's funeral pyres, thanks to Rammohon Roy's heroic efforts resulting in a 1829 legislation against widow immolation, but they were still destined to a life of unimaginable hardship. Denied access to property, family festivities and considered ominous, these "wicked widows", to borrow Tanika Sarkar's powerful phrase, were often subjected to cruel treatment by their families (Sarkar, 2008: 83). They were also put on a stringent diet aimed at robbing them of their youth, beauty and sexual urges. Considered a threat to the 'sacred' institution called the family, many widows were also subjected to unwanted pregnancies that were often followed by abortions. Committing suicide to escape such infamy had a tacit social approval. It was quite usual for a good number of widows to work in brothels which provided them with income and even some measure of prestige that were so crudely denied to them by their immediate families and society at large. ${ }^{1}$

It was not difficult for Vidyasagar to see the interconnections between these various socio-religious practises. Calling them deshachar or the customs of a country, he held them responsible for curtailing women's space both inside and outside home. According to Vidyasagar's biographers, much of the stimulus for his movement for women's emancipation also came from his first-hand experience of the agonies of child marriage and widowhood (see Ghose, 1973 \& Mitra, 1902, rpt. 2008). He was said to have been appalled at meeting the girlchild whom the elderly Vedanta scholar Sambhuchandra Vacaspati of Sanskrit College, Kolkata, had married to run his household, almost a few months before his death. Vidyasagar became so heartbroken by envisaging the life-long widowhood awaiting the bride that he walked out of his respected teacher's house, "refusing to touch water there henceforth" (Sarkar, 1997: 260). Consider, in addition, the young Vidyasagar's sad discovery of a childhood friend's early widowhood. On visiting the girl who was in her early teens, Vidyasagar found her starving on Ekadadshi in remembrance of her dead husband, with whom she only had a short-lived marriage (Mitra:172).

Vidyasagar's campaign for widow marriage gained momentum also because of the troubled conjugal experiences of young Bengali men, "moving to the city in quest of education and jobs, married off in their teens by parents to brides much younger and generally illiterate" (Sarkar 1997: 229). Colonial acculturation, often gained through exposures to English texts and occasional visits abroad, further introduced the Bengali gentry to a world devoid of child marriage and seclusion of women (Sarkar, 1985:71). The support for women's emancipation, yielded by the anglophile Young Bengal of Hindu College, Kolkata, aptly testified to the changes taking place in Bengali society. Within the broad context of a rapidly changing, gradually urban, English-educated, multi-layered middleclass society, it was possible for Vidyasagar to float his idea of widow marriage for public consideration.

Professor of Sanskrit and Principal of Sanskrit College, Vidyasagar's preeminent status as a public intellectual also helped draw attention to his cause. However, this did not mean that his programme was without its critics. Powerful landlords joined hands with orthodox sections of the society to launch signature campaigns against widow marriage (Ghose 1973: 259-61). Invoking the Shastra, they underscored the need to maintain traditional Bengali culture and family life as dictated by Hinduism. Many considered widowhood as a consequence of sins committed by a woman in her previous life. It was believed that a woman who had already become a widow 
would court widowhood if she were to be married off again. Since a Hindu woman was regarded to be wedded to her husband both for this and afterlife, which husband would be entitled to claim her in the afterlife if she were to be married off twice? It was even argued that if options for widow marriage were created, a woman could take advantage of this dispensation and arrange to have her husband killed to marry a man of her own choice (Anisuzzaman, 2000:41).

Even renowned writers such as Bankimchandra could not refrain from poking fun at Vidyasagar in his celebrated novel Bishabriksha (tr. Poison Tree) (1873): “A renowned pundit of Kolkata, Isvar Vidyasagar by name, has published a book on widow marriage. If he, who arranges marriages for the widows, is called a pundit, who can we call a fool?” (translation mine) (Chattopadhyay, 1360: 279). And we know that in his tract on Bahubibaha, i.e. multiple marriages, Bankimchandra had supported polygamy for the sake of maintaining patrilineality (Chattopadhyay, 1361: 314-19). This was on top of his glorification of the practice of sati and linking it to national regeneration in Kamalakanter Daptar:

"When I think that only some time back our women could die like this, then new hope rises up in me, then I have faith that we, too, have the seeds of greatness within us. Women of Bengal: You are the true jewels of this country" (quoted in Sarkar 2011: 395). ${ }^{2}$

At the core of the Bengali opposition to widow marriage was the fear of losing control over women's sexuality. In fact, the "assumption of innate and uncontrollable feminine sexuality ... was embedded in Hindu cultural traditions (Bandyopadhyay, 2011: 162). Henceforth, child marriage, which often resulted in widowhood, became an institutionalised form of regulating women's reproductive system. Bengali women's memoirs recounted how as young brides they were often unschooled in the rules of sexual cohabitation. Many simply submitted to their husband's physical needs, and sexual pleasure was not necessarily derived out of such often-enforced consummation of marriages. The death of Phulmonee, a child-bride of 10 or 11 , who bled to death after being raped by her 35-year old husband, was a case in point (Sarkar 2011: 400). Prominent newspapers rallied against attempts at condemning such tragic cases of child marriage, emphasising instead the importance of preserving Hindu customs even if it required a 'sacrifice' such as that made by Phulmonee (413).

Because widow marriage was prohibited in accordance with the general interpretation of the Shastra, Vidyasagar understood that unless he engaged with and reinterpreted the very Shastra that forbade widow marriage, it would be nearly impossible to mould public opinion in favour of his cause. He also realised that people would not have a favourable opinion of widow marriage if he wanted to promote it as their (secular) duty as citizens, but they might gradually change their minds if he could establish it as their religious responsibility. In addition, he wanted to rethink the very institution of marriage by emphasising conjugality and the rightful status of a wife within marriage. Although he fell short of claiming equality for the wife in marriage, he chose not to emphasise Hindu husband's canonical status as the god of the family, to whom wives must submit. In his 1850 tract titled "Balyabibaher Dosh" ("The Demerits of Child Marriage"), instead of viewing marriage in the light of the shared knowledge of the day as a union geared toward procreation, he interpreted it as the conjoining of two souls (Vidyasagar, 2002: 523-8). Importantly, he used the word pronoyor romantic love to describe marriage at a time when many married Bengali women, living in a joint patrilocal family, would have access to their husbands only at the dead of night. Stories of women 
failing to recognise their husbands had they accidentally run into them during the day were not unheard of. For Vidyasagar, the attainment of pronoy in marriage was impossible between minors who were married to each other, often without their consent. In such marriages, the child-bride was coerced into embracing motherhood despite being mentally unprepared either to bear children or to look after them.

In his two subsequent tracts on widow marriage, both published in 1855, Vidyasagar shifted his focus away from pronoy to emphasise the sexual need of the widow, a bold subject to tackle in his day. He singled out deshachar as the mother of all ills. Knowing that he would not be able to bypass the Shastra, Vidyasagar blamed deshachar alone for producing a skewed reading of the Shastra. Widows, he pointed out, were routinely subjected to various temptations of the body and often sexually exploited. As a result, unwanted pregnancies, abortions and prostitution were taking place with an alarming regularity. Invoking religious vocabulary, he labelled these incidents as sins and held Bengali men responsible for allowing them to happen. Note that Vidyasagar, despite his reformist rhetoric, cringed at granting any legitimacy to children born to widows out of wedlock. He called them bastards. However, far from portraying widows as deceitful, as Bankimchandra did, or wicked and hence prone to sexual lapses, Vidyasagar conjured up their abala existence, essentially a state of being in which one is denied access to speech. The widow in question, according to Vidyasagar, was forced to remain abala, literally meaning "without strength”, "no speech", "not spoken”, or simply "dumb", denoting a permanent state of silenced subalternity. ${ }^{3}$ However, while referring to the speechless state of the widow, Vidyasagar, the male reformer, did not necessarily refer to the suppressed energies resident within her, but to the hapless state she was in. Vidyasagar's decided focus was on invoking pity for Bengal's women. Empathy was pitted against the cruelty allegedly involved in the treatment of widows. The powerlessness of the widow, as he saw it, elicited his now-famous, almost poetic lamentation: "Thou speechless beings! I know not the crimes you had committed to atone for which you had to be born in India!" (translation mine) (Vidyasgar, 2002: 643). The erudition of a Sanskrit scholar and the affection of a Bengali mother thus found a joint expression in Vidyasagar's tracts.

What was the role of the British colonial administration when this debate on widow marriage was unfolding in Bengal? According to Partha Chatterjee, the colonial government's overzealous tendency in branding Hindu scripts and customs as backward and dispensable eventually produced a backlash against efforts, as those taken by Vidyasagar, at reinterpreting Hindu texts to combat misogynist customs:

"A central element in the ideological justification of British colonial rule was the criticism of the "degenerate and barbaric" social customs of the Indian people, sanctioned, or so it was believed, by the religious tradition. Alongside the project of instituting orderly, lawful, and rational procedures of governance, therefore, colonialism saw itself as performing a "civilizing mission". ... Indians themselves must come to believe in the unworthiness of their traditional customs and embrace the new forms of civilized and rational social order" (Chatterjee 1999: 118-9).

This might explain why during India's independence struggle, Indian nationalists championed the woman as the mother goddess of India. We recall here Sandip, the Swadeshi activist, who famously does this in Rabindranath Tagore's The Home and the World (1916, rpt. 2005) by placing Bimala, his friend's wife, on a pedestal to be worshipped. This renewed veneration bestowed on women by the nationalists was to remind them of 
their status as grihalakshmi, i.e. the goddess of home, and to ask them to consider domesticity as quintessentially Indian. By glorifying life in the zenana, the nationalists, in a sense, worked against the gains achieved by the likes of Vidyasagar. Unsurprisingly, the Bengali gentry's appropriation of Vidyasagar's various programmes ultimately resulted in "a fairly limited and controlled emancipation of wives within a framework of more companionate conjugality" (Sarkar, 1997: 229). Women were seen, and the necessity of granting them considerable freedom considered, in the context of marriage and domesticity, and not necessarily outside it. That in the very year of Vidyasagar's death, the gentry was divided as to whether to support or to condemn the causes resulting in Phulmonee's death underscored their essential conservative streak.

The opposition encountered by Vidyasagar during his lifetime both from the Bengali middleclass as well as prominent figures such as Bankimchandra speaks volumes about middleclass tendencies in (often) retarding a social movement it helped start and advance. The eventual split within the Bengali middleclass regarding widow marriage, thanks to its vacillation between progress and conservatism, did not allow Vidyasagar's efforts to be fully realised. Although significant changes to the lives of women segregated in the zenana were gradually introduced, women's participation in the world was not, in this process, necessarily ensured. Not many widows married under the Widow Remarriage Act of 1856 either. ${ }^{4}$ Vidyasagar's project for Bengal's widows also had a gaping hole in it. It left Muslim women entirely out of its consideration. This was something Bankimchandra was the first to note inadvertently while criticising Muslim men for their Koran-sanctioned polygamy, and Vidyasagar's apparent reluctance in acknowledging that in his 'one-sided' criticism of Kulin
Brahmin marriages (Bankimchandra, 1361: 318). Muslim women would have to wait for another social reformer in the figure of Rokeya Sakhawat Hossain $(1880$ - 1932) to find out for themselves that life outside the zenana could be pregnant with possibilities.

\section{Acknowledgements}

This article was written at Wadham College, University of Oxford, UK, where I studied as a British Commonwealth Academic Staff Scholar. I thank Oxford for providing me with excellent facilities for research. I also take this opportunity to thank my mother, Shaheda Khanam Chowdhury, Principal House Tutor (rtd.) of Rokeya Hall, Dhaka University, Bangladesh, for her constant encouragement and support for my academic work. Multiple strokes haveleft her bereft of speech and motion; otherwise, she would have expressed her happiness in seeing this article in print.

\section{References}

1. According to one estimate, in 1853, the population of prostitutes in Kolkata was 12,419. By 1867, more than 30,000 prostitutes were reported to be working in Kolkata, $90 \%$ of them, according to Amritabazar, a contemporary newspaper, were widows (Murshid, 1984: 16-7).

2. To be fair though, in the case of widow marriage, Bankimchandra was against any intervention to be possibly made by Rajshakti, i.e. the British. Widow marriage had better be left to the Indians to be decided on their own - such was his stance. Vidyasagar's strategy was two-pronged. He carried out his social campaign while also understanding, probably better than Bankimchandra, that unless widow marriage was recognised by the state, it would have no legal validity whatsoever. 
3. The image of the silenced woman was a pertinent one to invoke, especially in Bengal, where the eighth/twelfth-century astrologer Khana, thanks to her vachan/utterings, became so famous that she was considered a threat to the positions of residentastrologers held by none other than Varaha, her father-in-law, and Mihir, her husband, at the court of King Vikramaditya. For her alleged aspiration to usurp Mihir's position, Khana's tongue was cut out by her husband as a punishment, ultimately leading to her death. Notwithstanding, many of Khana's agricultural and ecological wisdom, in the form of maxims, have survived and are very much in circulation in rural Bengal, yielding her a mythic status (Islam, 2003: 82). It is also not without significance that Taslima Nasrin (1962 -), the controversial Bangladeshi feminist writer, would call the third volume of her autobiography, banned both in Bangladesh and India, Ka (2004) or "speak up", to invoke mainly this long history of women speaking, being silenced, and spoken for.

4. Statistics is arguably an insufficient marker to explain the longterm impact Vidyasagar's programme has so far had on Bengal. For instance, the (statistically) limited success of his widow marriage campaign could not deter Madhusudan Dutt (1824 '73) and Rabindranath Tagore (1861 - 1941), just to name the two towering figures of Bengali literature, from championing Vidyasagar's compassion and courage. Vidyasagar's compassion was highlighted in Dutt's celebrated sonnets, while Tagore's epitaph for the social reformer lauded his courage under fire. That, in recent years, the Columbia University Press (USA) and Routledge (India, UK, USA) have brought out fresh translations of Vidyasagar's tracts on widow marriage (2012) and his biography (2014), further demonstrates a resurgence of interest in Vidyasagar both in the West and in the Indian sub-continent.

\section{Bibliography}

Anisuzzaman, BangaliNari: Sahitye O Samaje (tr. Bengali Women in Literature and Society), (Dhaka: Sahitya Prakash) 2000.
Bhabanicharan Bandyopadhyay, Kolikata Kamalalaya (tr. Kolkata, the House of Fortune), (Kolkata: Ranjan Publishing House) 1343.

Sekhar Bandyopadhyay, "Caste, Widow-remarriage, and the Reform of Popular Culture in Colonial Bengal”, Sumit. Sarkar \& Tanika Sarkar, ed. Women and Social Reform in Modern India: Vol. I, (New Delhi: Permanent Black. 2011), pp. 145-171.

Maleka Begum \& Huq S.A, Ami Naree: Tinsho Bachharer Bangali Nareer Itihash: Atharo - BishShatak(tr. I'm a Woman: The History of Bengali Women from the Eighteenth to the Twentieth centuries), (Dhaka: University Press Limited) 2001.

Sambuddha Chakrabarti, Andare Antare: Unish Shatake Bangali Bhadramahila (tr. The Bengali Gentlewoman in the Nineteenthcentury), (Dhaka: University Press Limited) 1998.

Partha Chatterjee, The Partha Chatterjee Omnibus, (New Delhi: Oxford University Press) 1999.

Bankim Chattopadhayay, Bankim Rachanabali Vol. I (tr. Collected Works of Bankim), (Kolkata: Sahitya Sangsad) 1360. Bankim Rachanabali Vol. II, (Kolkata: Sahitya Sangsad) 1361.

Saratchandra Chattopadhayay, Devdas, (Delhi: Penguin) 1917 (rpt. 2002).

Nirad. C. Chaudhuri, Bangali Jibane Ramani (tr. Women in Bengali Life), (Kolkata: Mitro O Ghose Publishers) 1968.

Asma Chowdhury, "Samakalin Samajik Prekshapate Vidyasagar” (tr. "Vidyasagar in contemporary social context"), Mijanur Rahmaner Traimasik Patrika: Vidyasagar Sangkha, Vol. 13:1 (April-June), 1997, p. 279-289.

Benoy Ghose, Vidyasagar O Bangali Samaj (tr. Vidyasagar and Bengali Society), (Kolkata: Orient Longman Ltd.) 1973.

Brian A. Hatcher, Vidyasagar: The Life and After-Life of an Eminent Indian, (Routledge: India \& UK) 2014. 
Abdul Hai \& Anisuzzaman, ed. Vidyasagar Rachanasamgraha (tr. Complete Works of Vidyasagar), (Dhaka, Studentways, 1968).

Sirajul Islam, ed. "Khana”, Banglapedia: National Encyclopedia of Bangladesh Vol. VI, (Dhaka: Asiatic Society of Bangladesh, 2003).

Subal Chandra Mitra, Isvar Chandra Vidyasagar: Story of His Life and Work, (Kolkata: Parul Prakashani) 1902 (rpt. 2008).

Golam Murshid, Samaj Sanskar Andolon O Bangla Natak: 18541876 (tr. Social Reform Movements and Bengali Dramatic Writings: 1854-1876), (Dhaka: Bangla Academy) 1984.

Sankocher Bihabalata: Adhunikatar Abhighate Banga Ramanir Pratikriya: 1849-1905 (tr. Reluctant Debutante: Responses of Bengali Women to Modernization; 1849-1905), (Dhaka: Bangla Academy) 1985.

Taslima Nasrin, Ka (tr. Speak Up), (Dhaka: Chardik) 2003.

Bharati Ray, "Women of Bengal: Transformation in ideas and ideals, 1900-1947”, Social Scientist, Vol. 19: 5/6 (May-June), 1991, p. 3-23.

Sumit Sarkar, A Critique of Colonial India, (Calcutta: Papyrus) 1985.

, Writing Social History, (New Delhi: Oxford University Press) 1997.

Tanika Sarkar, "Wicked widows: Law and Faith in Nineteenthcentury Public Sphere Debates", Anindita Ghosh, ed. Behind the Veil: Resistance, Women and the Everyday in Colonial South Asia, (Hampshire: Palgrave Macmillan, 2008), p. 83-116.

, "Conjugality and Hindu Nationalism: Resisting Colonial Reason and the Death of a Child-wife”, Sumit Sarkar \& Tanika Sarkar, ed. Women and Social Reform in Modern India: Vol. I, (New Delhi: Permanent Black, 2011), p. 385-419.
Rabindranath Tagore, The Home and the World, (London: Penguin) 1916 (rpt. 2005).

Ishvar Chandra Vidyasagar, Vidyasagar Rachanabali Vols. I \& II (tr. Complete Works of Vidyasagar), (Kolkata: Tuli-Kalam) 2002.

Isvar Chandra Vidyasagar, Hindu Widow Marriage, (New York: Columbia University Press) 2012. 